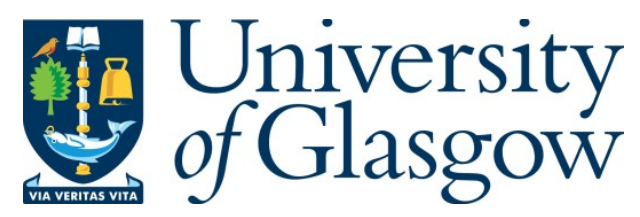

Cresswell, A., Kato, H., Onda, Y., and Nanba, K. (2016) Evaluation of forest decontamination using radiometric measurements. Journal of Environmental Radioactivity, 164, pp. 133-144.

There may be differences between this version and the published version. You are advised to consult the publisher's version if you wish to cite from it.

http://eprints.gla.ac.uk/121372/

Deposited on: 03 August 2016

Enlighten - Research publications by members of the University of Glasgow http://eprints.gla.ac.uk 


\section{Evaluation of Forest Decontamination Using Radiometric Measurements}

2 Alan J. Cresswell ${ }^{\dagger *}$, Hiroaki Kato ${ }^{\ddagger}$, Yuichi Onda ${ }^{\ddagger}$, Kenji Nanba $^{\dagger}$

$3{ }^{\dagger}$ Institute of Environmental Radioactivity, Fukushima University, 1 Kanayagawa, Fukushima

4 960-1296, Japan

$5 \quad{ }^{\ddagger}$ Center for Research in Isotopes and Environmental Dynamics, University of Tsukuba, 1-1-1

6 Tennodai, Tsukuba, Ibaraki 305-8572, Japan

$7 \quad$ * Corresponding Author. Present address: Scottish Universities Environmental Research

8 Centre, East Kilbride, Glasgow G75 0QF, UK. E-mail: alan.cresswell@glasgow.ac.uk

\section{Abstract}

11 An experiment has been conducted to evaluate the additional dose reduction by clear felling 12 contaminated forestry in Fukushima Prefecture, Japan, and using the timber to cover the areas 13 with wood chips. A portable gamma spectrometry system, comprising a backpack containing 14 a 3x3" $\mathrm{NaI}(\mathrm{Tl})$ detector with digital spectrometer and GPS receiver, has been used to map dose rate and radionuclide activity concentrations before, after and at stages during this experiment. The data show the effect of the different stages of the experiment on dose rate at different locations around the site. The spectrometric data have allowed the assessment of the contributions of natural and anthropogenic radionuclides to the dose rate at different parts of the site before and after the experiment. This has clearly demonstrated the value of radiometric methods in evaluating remediation, and the effect of other environmental processes. The value of spectrometric methods which directly measure radionuclide concentrations has also been shown, especially through the identification of the contribution

23 of natural and anthropogenic activity to the measured dose rate. The experiment has shown

24 that clearing trees and applying wood chips can reduce dose rates by $10-15 \%$ beyond that achieved by just clearing the forest litter and natural redistribution of radiocaesium. 


\section{Keywords}

Radiocaesium; Gamma Dose Rate; Fukushima Nuclear Accident

\section{Introduction}

Following the Fukushima Daiichi Nuclear Power Plant (FDNPP) accident in March 2011, large areas of Fukushima Prefecture were contaminated with radiocaesium. Approximately $70 \%$ of the contaminated area is forested, providing a reservoir for contamination that is largely recycled within the forests (Hashimoto et.al. 2013). Remediation of forests is particularly challenging, and current practice in Japan is to reduce the dose rate in and around buildings by the removal of forest litter and undergrowth to a distance of $20 \mathrm{~m}$ from roads and buildings. Decontamination model projects conducted by the Japan Atomic Energy Agency (JAEA) have demonstrated reductions in dose rates within remediated forest areas of 30-50\% by such methods, with higher reductions achieved on open areas (Hardie \& McKinley 2014, Nakayama et.al. 2015). Similar remediation factors have been observed in backpack surveys of a forest remediation trial, involving litter removal, near Iwaki

42 (Sanderson et.al. 2016).

Another potential method for forest remediation is to cut down trees near households. This has advantages since it eliminates the risk of future deposition through litter fall and through fall (Kato et.al. 2015). However, this approach has not yet been tested, and therefore there is no data available to assess the effect of forest removal on dose rate.

47 Radiometric surveys using backpacks are ideal to evaluate forest dose rates and the effect of decontamination. Within forests dose is spatially highly heterogeneous, and the random distribution of tree trunks make regular grid data measurements difficult. Backpack surveys

50 are capable of total area coverage, and can produce maps of the distribution of dose rate and 
51 radionuclide deposition. Repeat surveys can monitor the changes in the spatial distribution of dose rate due to forest decontamination work.

In the work described here, an experiment has been conducted to assess the effect of additional decontamination measures on the dose rate recorded at the edge of contaminated forests. Trees along the edge of the forest, to a distance of $10 \mathrm{~m}$, have been felled, and wood chips derived from the felled trees applied to the ground surface. Assuming a density of approximately $500 \mathrm{~kg} \mathrm{~m}^{-3}, 1-2 \mathrm{~cm}$ of wood chips over a near-infinite surface would be expected to reduce radiocaesium full energy count rates by $10-20 \%$ and dose rates by $7-17 \%$. When applied to smaller areas the expected reductions will be smaller. At various stages during the experiment portable gamma spectrometry methods were used to map the spatial distribution of dose rate and deposited activity within and around the remediated area. These data are used to assess the reduction in dose rate achieved at different points in the experiment.

\section{Methodology}

\subsection{Site description}

The experiment was conducted at the former Yamakiya Elementary School, Kawamata town $\left(37^{\circ} 36.169 \mathrm{~N}, 140^{\circ} 40.582 \mathrm{E}\right)$, approximately $40 \mathrm{~km}$ from the FDNPP. This is within the evacuated area, categorised as an area where preparations are underway to allow residents to return to their homes. The location of the site is shown in Fig. 1. The site has two connected buildings housing the elementary school and a separate building for a kindergarten, with a sports field on a levelled terrace. A forest area, with a mixture of cedar, beech, Japanese oak and red pine, is situated to the north and east of the school buildings. To the east, the forest is dominated by deciduous trees and is approximately $10 \mathrm{~m}$ above the school buildings with a grassed slope at approximately $45^{\circ}$ to the kindergarten building and a small enclosed space. 
north, the forest coniferous trees are more numerous and descends northwards below the school terrace, with the edge of the forest descending until it is level with the elementary school building. The lower parts of this slope are dominated by red pine. The forest site is being used for ongoing studies of the behaviour of radiocaesium in forest environments, including studies of interception and transfer from the forest canopy (Kato \& Onda 2014, Kato et.al. 2015) and depth distribution in soils (Takahashi et.al. 2015).

Decontamination work was carried out at the school in 2012, following current practice for remediation of contaminated areas. Top soil was removed from the sports field and grassed areas around the school and replaced with sand or fresh turf between May and September 2012, and leaf litter removed from the forest areas around the school to a distance of $20 \mathrm{~m}$ from the forest edge between October and December 2012.

To facilitate comparisons between surveys, the site was divided into a series of areas (shown in Fig. 2); A to D for artificial surfaces around the school, Area C also includes a small ornamental garden area outside the main entrance. E to $\mathrm{H}$ for the forest and grassed areas. Area E was the section of forest that was felled during this work, and with area G had previously been remediated by the removal of leaf litter. Areas E, F, and G have been divided into three sub areas, and area $\mathrm{H}$ two sub areas. These areas are described in Table 1. Static dose rate measurements were also collected at marked positions on two overlapping grids (Fig. 2). Both grids had $10 \mathrm{~m}$ spacing, with one axis parallel to the edge of the forest to the east of the school. On the northern part of the site, the forest edge runs north-south, with the axes aligned along the western edge of area E2 and the southern edge of area E3. South of the kindergarten building the forest edge turns slightly to the west, resulting in a rotational offset between the grids, with the axis here aligned along the western edge of area E1.

\subsection{Experimental timescale}


101 Surveys were conducted prior to the start of the experiment, at intervals during the experiment, and following completion of the experiment. Each survey included the area of

103 forest which was felled, and surrounding areas of forest and school grounds, but some of the surveys did not include all of the sports field and areas around the school more distant from the experimental area. Details of these measurements are given in Table 2. The trees to a distance of approximately $10 \mathrm{~m}$ into the forest were felled on the $8^{\text {th }}, 9^{\text {th }}$ (Areas E1 and part of

107 E2), $12^{\text {th }}$ and $13^{\text {th }}$ (part of Area E2 and Area E3) November 2014, with the trunks cut and temporarily stacked on site at the edge of the remaining forest (see Fig. 3 (d)). The majority of the tree trunks were subsequently chipped on site, with the chips applied to part of the

110 slope between the 23rd and 30th November (Area F1). Branches and other litter left on the

111 felled area (Area E) were mostly removed between the 15th and 23rd November, with

112 substantial stacks of branches remaining along the bottom of the slope to the east of the

113 school buildings (the southern end of Area F1) and Area D. Following an interruption in

114 work during the winter, the remaining area of slope (Area F2) was covered in wood chips,

115 and the majority of the remaining piles of branches removed on the 28th April 2015 with the

116 last few remaining material removed after that. Figure 3 shows photographs of the site at 117 different stages of the decontamination experiment.

\subsection{Instrumentation and data processing}

120 Measurements were conducted using a Portable Gamma Spectrometry System developed at 121 the Scottish Universities Environmental Research Centre (SUERC). The system comprises a weather proof container housing a 3x3” $\mathrm{NaI}(\mathrm{Tl})$ detector with a digital spectrometer and integrated HV supply, and a GPS receiver (Cresswell et.al. 2013). For this work, this was

124 carried in a backpack with a measurement time of $5 \mathrm{~s}$ for each spectrum, corresponding to 125 averaging the signal over a distance of approximately $2 \mathrm{~m}$. As far as possible within the 
126 constraints of the terrain, a dense survey pattern of parallel lines 1-2 m apart was maintained.

127 A netbook or tablet computer was used to power the system, and run custom software that

128 continuously logged spectra with associated positional information, and run real-time

129 analysis using predetermined calibration parameters. Real-time data analysis used a spectral

130 windows with stripping algorithm to calculate activity per unit area for ${ }^{137} \mathrm{Cs}$ and ${ }^{134} \mathrm{Cs}$, and

131 activity per unit mass for ${ }^{40} \mathrm{~K},{ }^{214} \mathrm{Bi}\left({ }^{238} \mathrm{U}\right.$ decay series) and ${ }^{208} \mathrm{Tl}\left({ }^{232} \mathrm{Th}\right.$ decay series), and a

132 scaled count rate above $450 \mathrm{keV}$ to calculate total terrestrial gamma dose rate. Analysis

133 includes subtraction of a background recorded from a plastic boat over open water,

134 accounting for internal activity within the detector and the cosmic dose rate. For the detector

135 used here, these measurements were conducted on Loch Lomond, Scotland $\left(56^{\circ} 8 \mathrm{~N}, 4^{\circ} 38 \mathrm{~W}\right)$,

136 it is recognised that the sea level cosmic background is slightly higher for these

137 measurements than would be the case in Fukushima, but this is an insignificant error

138 compared to the terrestrial radiation. This method, applied to airborne measurements, has

139 been described in numerous places including IAEA (1991, 2003) and Sanderson et.al. (1994),

140 Cresswell et.al. (2006) also includes the derivation of uncertainties on measurements.

141 The calibration parameters for the real-time analysis, which take account of the shielding

142 effect of the operator (Buchanan et.al. 2016), were validated using reference sites in Scotland

143 and Japan (Cresswell et.al. 2013, Sanderson et.al. 2013). The parameters for radiocaesium

144 and natural activity concentrations assume an open field geometry, and do not account for

145 shielding effects from trees or contributions to the radiation measured from activity in the

146 canopy. Measurements in a cedar forest near Iwaki demonstrated that the contribution to the

147 measured signal from activity in the canopy is no more than a few percent, even if the canopy

148 retains a significant fraction of the activity (Sanderson et.al. 2016). An assessment of the

149 shielding effects of trees and understory plants is ongoing, but initial analysis suggests that

150 this results in a reduction in count rate of less than $20 \%$ compared to the open field for forests 
of similar density to this site. The relative changes in activity concentration and dose rate in

152

153

154

155

156

157

158

159

160

161

162

163

164

165

166

167

168

169

170

171

172

173

174

175

areas that are not physically changed during this experiment will not be affected by this

attenuation effect. However, it may be necessary to consider this effect in comparing surveys of areas where trees were removed.

In open field conditions, the detector field of view is approximately 10-15 m radius, depending on source depth profile (Tyler et.al. 1996). The effect of attenuation by trees will be to reduce this field of view, to less than $10 \mathrm{~m}$. This has not, however, been determined precisely to date.

For natural series radionuclides, the calibration assumes a uniform depth distribution. For radiocaesium, the calibration assumes an exponential depth distribution with a relaxation mass depth of $1.0 \mathrm{~g} \mathrm{~cm}^{-2}$, which matches calibration sites established in Fukushima in 2012 (Sanderson et.al. 2013). Soil samples collected from the forest at Yamakiya between July 2011 and December 2012 (Takahashi et.al. 2015) show relaxation mass depths, excluding the litter layer, of between $0.4-0.9 \mathrm{~g} \mathrm{~cm}^{-2}$. Including the litter layer and subsequent measurements (see Table S.1, Supplementary Material) the range of mass depths is $0.3-0.4 \mathrm{~g} \mathrm{~cm}^{-2}$. Three soil cores collected in May 2016 at a different location within the school forest had mass depths between 0.5 and $1.1 \mathrm{~g} \mathrm{~cm}^{-2}$.Therefore, although it is likely that the mass depth across the site may be less than the assumed mass depth of $1.0 \mathrm{~g} \mathrm{~cm}^{-2}$, this is still appropriate for this location. The uncertainty on mass depth results in a systematic error on the activity per unit area of less than $20 \%$, but has no impact on the relative values measured at different times assuming no change in depth profile between measurements. Measurements at a reference site on the Fukushima University just prior to field work at Yamakiya in November 2014, and at the Fukushima Prefecture Fruit Tree Research Institute in April 2015, confirmed the functionality of the detector and the validity of the calibration coefficients. These sites have been extensively sampled with activity per unit area and depth profiles determined by 
laboratory gamma spectrometry relative to international reference materials (Sanderson et.al.

177

178

179

180

181

182

183

184

185

186

187

188

189

190

191

192

193

194

195

196

197

198

2013).

The dose rate $\left(\mu \mathrm{Gy} \mathrm{h} \mathrm{h}^{-1}\right)$ and ${ }^{137} \mathrm{Cs}$ and ${ }^{134} \mathrm{Cs}$ activity per unit area $\left(\mathrm{kBq} \mathrm{m}^{-2}\right)$ and natural series activity per unit mass $\left(\mathrm{Bq} \mathrm{kg}^{-1}\right)$ have been mapped using a modified inverse distance weighting algorithm, with the average value for each map pixel being given by:

$$
\bar{A}=\frac{\sum_{i} w_{i} A_{i}}{\sum_{i} w_{i}}
$$

where the summation is across all points $i$ within a maximum range $r_{\max }$ of the map pixel.

The weight assigned to each point, $w_{i}$, is given by:

$$
w_{i}=\left(r_{i}+\Gamma\right)^{-p}
$$

Where $r_{i}$ is the distance between the measurement point and the map pixel, $\Gamma$ is a constant that flattens the distribution at small values of $r_{i}$, and $p$ is a power. For this work, a power $p=1.7, \Gamma=1 \mathrm{~m}$ and maximum range $r_{\max }=10 \mathrm{~m}$ have been used. The combination of power and flattening constant results in 95\% of the weight being carried by measurements within $4 \mathrm{~m}$ of the pixel, approximately comparable to the field of view of the detector. The maximum range allows two-three measurements in any direction to be included in the weighted mean value. To allow comparisons between data collected on different occasions, a spatial regridding algorithm is employed (Sanderson et.al 2004, 2008). This uses the modified inverse distance weighting algorithm to determine values for dose rate, activity per unit area or activity per unit mass in each of a grid of cells. For this work, this has been done using cells of $5 \times 5 \mathrm{~m}$, and the same parameters for the interpolation as were used to generate the mapped data. The surveys were conducted over an extended period in autumn and spring. There is the potential for changing environmental conditions, in particular soil water content, to influence the radiometric data. If it is assumed that the activity per unit dry mass for natural radionuclides is constant then variations in the measured activity per unit mass would reflect changing soil water content. With the backpack system used here the ${ }^{40} \mathrm{~K}$ peak count rate is 
199 used, the peaks used for U-series (1764 $\left.\mathrm{keV}^{214} \mathrm{Bi}\right)$ and Th-series $\left(2614 \mathrm{keV}^{208} \mathrm{Tl}\right)$ activity

200 measurement have lower intensities and are measured with lower efficiency, and hence carry

201 substantial statistical imprecision. Ratios for different parts of the survey area are produced

202 between the ${ }^{40} \mathrm{~K}$ count rates for each survey to the first survey, with average ratios produced

203 for the areas with predominantly artificial surfaces and the forests. A relative soil density

204 compared to the initial survey conditions, from which a relative mean mass depth for

205 radiocaesium can be determined. Interpolation of fluence rates for ${ }^{137} \mathrm{Cs}(662 \mathrm{keV})$ and ${ }^{134} \mathrm{Cs}$

206 (795 keV) and dose rate conversion coefficients tabulated by ICRU (1994) as a function of

207 mass depth can then be used to adjust the measured activity per unit area for radiocaesium

208 and dose rates to values for the environmental conditions of the initial survey.

209 To better understand the origins of the dose rates observed, dose rate apportionment has

210 been used to determine the contribution of the dose rate from natural radionuclides and

211 radiocaesium. This uses conversion factors to determine air kerma dose rate from the activity

212 concentrations measured using the portable gamma spectrometry system, and the percentage

213 of the total dose rate from each of these sources.

214 Measurements of dose rate (ambient dose, $\mu \mathrm{Sv} \mathrm{h}^{-1}$ ) were also collected using a TCS-172B

215 survey meter (Aloka Hitachi Medical, Japan, calibrated by Chiyoda Technology Corporation,

216 Japan, on September $24^{\text {th }} 2014$ ) at a height of $1 \mathrm{~m}$. During most of the surveys, the dose rates

217 determined with the backpack from 4-8 measurements while standing at some of these

218 positions were also recorded.

219

220

3. Results and discussion

221

\subsection{Detector response validation}

222 Soil layer samples were collected on four occasions between July 2011 and December 2012

223 from a location within the forest to the east of the school which had not been remediated 
224 (Takahashi et.al. 2015), with three additional samples collected on an annual basis

225

226

227

228

229

230

231

232

233

234

235

236

237

238

239

240

241

242

243

subsequently (see Table S.1, Supplementary Material) with a mean ( \pm standard deviation on seven measurements) activity per unit area for ${ }^{137} \mathrm{Cs}$ of $341 \pm 85 \mathrm{kBq} \mathrm{m}{ }^{-2}$ and for ${ }^{134} \mathrm{Cs}$ of 100 $\pm 19 \mathrm{kBq} \mathrm{m}^{-2}$ (decay corrected to November 2014). The average activity per unit area measured with the backpack system within $10 \mathrm{~m}$ of this location on the $8^{\text {th }}$ November 2014 , prior to felling of trees, was $264 \pm 67$ and $89 \pm 23 \mathrm{kBq} \mathrm{m}$. for ${ }^{137} \mathrm{Cs}$ and ${ }^{134} \mathrm{Cs}$ respectively. Although this single point observation of non-contemporaneous measurements is not ideal, the backpack and soil samples agree within measurement uncertainties. Together with the extensive detector validation previously conducted this does indicate that the calibration assumptions are valid for this forest environment, and suggests that the effects of attenuation by the trees and radiation from the canopy are relatively small.

During the surveys with the portable gamma spectrometry system, dose rates were recorded at some of the measurement points used to conduct dose rate measurements using the dose rate meter. Table S.2 in the supplementary material gives the dose rates recorded at these locations using the SUERC spectrometer, and measurements with the dose rate meter at similar stages in the experiment. Figure 4 shows the measurements by the two instruments at common points. The slope of a linear regression through these points reflects the approximate relationship between the different dose rate units, $1 \mathrm{~Gy} \approx 1.2 \mathrm{~Sv}$, with the small non-zero intercept probably reflecting differences in assumed instrumental background. Again, these observations support the prior validation of the backpack instrument.

\subsection{Environmental conditions}

As noted, there is evidence of variations in environmental conditions, probably soil water content, affecting the activity concentrations and dose rates measured by the backpack system. Average values for the activity concentrations recorded for different parts of the site 
249 for each survey are given in Table S.3 in the supplementary material. Ratios of ${ }^{40} \mathrm{~K}$ activity

250 per unit mass for each survey relative to the initial survey were used to quantify these

251 variations. It is observed that for the artificial surfaces (areas A-D) these ratios were not

252 significantly different from unity, and hence no corrections were required for these areas.

253 However, within the forest (areas E-H) there were some significant variation in these ratios

254 for different surveys, but with less variation between different parts of the forest for each

255 survey. An average value of this ratio for all the forest areas was therefore used for each

256 survey.

257 On the assumption that soil water content was the only variable, and that the ${ }^{40} \mathrm{~K}$ activity

258 per unit mass was constant with depth, these ratios can be used to calculate relative soil

259 density changes, and hence relative mass depth changes for radiocaesium. Other factors may

260 also contribute to variability in dose rates, including atmospheric conditions and variability in

261 cosmic ray intensity. All the surveys were conducted in dry weather. It would be expected

262 that air humidity and cosmic ray intensity would affect both forest and artificial areas, and the

263 absence of an appreciable effect on the artificial surfaces suggests that these are not

264 significant contributions to the observed variations in natural activity count rates. Correction

265 factors for the radiocaesium activity per unit area and dose rate have been calculated using

266 tabulated photon flux data and dose rate conversion coefficients (ICRU, 1994) for the mass

267 depths thus estimated. The ${ }^{40} \mathrm{~K}$ activity ratios, relative soil density and correction factors

268 determined are given in Table S.4 in the supplementary material, with the corrected values

269 also given in Table S.3.

270 For the surveys on the $14-15^{\text {th }}$ November 2014 and $28^{\text {th }}$ April 2015 the average ${ }^{40} K$ activity

271 per unit mass in the forest areas (areas E-H) was smaller than for the initial survey on the $7^{\text {th }}$ -

$2728^{\text {th }}$ November 2014, suggesting that the ground was wetter at these times. Conversely, for the

$27323^{\text {rd }}$ and $30^{\text {th }}$ November 2014 and especially the $27^{\text {th }}$ May 2015 the measured activity 
274 concentrations were higher, suggesting the ground was drier. It is also noted that on the $15^{\text {th }}$

275 November 2014 survey an enhancement in ${ }^{214} \mathrm{Bi}$ activity per unit mass is measured in all

276 areas, without corresponding variations in the ${ }^{40} \mathrm{~K}$ and ${ }^{208} \mathrm{Tl}$ values, which suggests a radon

277 related effect on that day. The impact on total dose rate is very small, and this radon effect

278 has not been corrected for. The advantage of spectrometric measurements compared to dose

279 rate instruments, with the use of natural activity to assess environmental conditions, is

280 evident from these analyses.

281

282

\subsection{Dose rate variation with time}

The average dose rate for each area around the site, following adjustments for

environmental variations and the decay of ${ }^{134} \mathrm{Cs}$, have been plotted in Fig. 5. For the artificial

surfaces around the school the dose rate is approximately constant through the experimental

period, with decreases of approximately $15 \%$ for area A (sports field) and approximately $25 \%$

for area B (at the far end of the school). These are the most exposed areas on the site, and as

such may be prone to enhanced weathering effects, resulting in greater redistribution of

activity. Areas C (in front of the main entrance) and D (nearest the forest) have slightly

higher dose rates, probably attributable to the proximity to vegetated areas, which are

approximately unchanged over the duration of the surveys.

The area of forest where trees were felled (E) shows a decrease in dose rate following the

felling of trees, followed by a further reduction while tree branches are removed, with no significant additional dose rate reductions following the application of wood chips to the adjacent area $(F)$. Overall, a reduction in dose rate of $15 \pm 5 \%$ is observed in this area as a result of felling the trees. The area (F) between the felled forest and the school shows initial increases in dose rate with the felling of trees, especially to the northern and southern parts of the area where tree branches were stacked. This is most likely the result of the accumulation 
of branches, which would carry some radiocaesium contamination, in this area. Clearing the branches and application of wood chips reduces the dose rate to $9 \pm 4 \%$ below the initial values. For the forest area adjacent to the felled area $(G)$ a dose rate reduction following the felling of trees was observed, with an increase while this area was used to stack tree branches prior to production of wood chips. After clearing these branches, an overall dose rate reduction of $12 \pm 4 \%$ is observed. Area $\mathrm{H}$, the control area not directly affected by the experiment, shows a large reduction in dose rate in the second part of November 2014, for reasons that are unclear, but overall only a small dose rate reduction $(7 \pm 3 \%)$ during the course of the experiment for most of the area. A much larger reduction in dose rate is observed for the northern part of this area (H2) in May 2015, which is also unexplained.

309 Dose rate apportionments for different parts of the site are shown in Fig. 6, for data recorded at each stage in the experiment. Areas A, B, C and D all have similar natural series

311 activity concentrations, with natural dose rates of 0.050-0.055 $\mu \mathrm{Gy} \mathrm{h} \mathrm{h}^{-1}$. Area A, the school

312 sports field, has the smallest contribution from radiocaesium to the total dose rate (65\%).

313 Areas B, C and D contain some natural surfaces with small ornamental trees, with area D

314 adjacent to the forest area, and as a consequence have slightly higher radiocaesium

315 concentrations from these harder to remediate surfaces (contributing $75-80 \%$ of the dose 316 rate).

317 At the conclusion of the experiment, the sports field (A) remains unchanged with the other 318 areas around the school. (B, C and D) showing a small reduction in dose rate, an average of 5 $319 \pm 3 \%$ beyond that from the physical decay of ${ }^{134} \mathrm{Cs}$, as previously noted. In all the forest areas, the dose rate from natural series activity is approximately half that from the artificial surfaces of the school grounds (0.017-0.027 $\left.\mu \mathrm{Gy} \mathrm{h} \mathrm{h}^{-1}\right)$, reflecting higher natural series activity concentrations in the construction materials of the school, and potentially the sand used to replace contaminated soil, compared to the local soils. Area F, the grassed slope between the 
forest and the school, has natural dose rates between the two extremes reflecting contributions from both environments. The variations in natural dose rates within each area between surveys are within measurement uncertainties and demonstrate that the adjustments for soil moisture content assuming constant natural series activity have removed variations from this source. The reductions in the contributions from radioacaesium follow the same pattern as previously noted for the total dose rate.

330

\subsection{Dose rate and ${ }^{137} \mathrm{Cs}$ distribution at different stages during the experiment} are shown in Figs. 7 and 8. The ${ }^{134} \mathrm{Cs}$ distributions match the ${ }^{137} \mathrm{Cs}$ distributions and the corresponding maps are not reproduced here. These maps include adjustments to account for the physical decay of ${ }^{134} \mathrm{Cs}$ and changing environmental conditions. remediation, with the school sports fields showing dose rates below $0.15 \mu \mathrm{Gy} \mathrm{h}{ }^{-1}$ and ${ }^{137} \mathrm{Cs}$ below $50 \mathrm{kBq} \mathrm{m}^{-2}$, other areas around the school showing dose rates below $0.40 \mu \mathrm{Gy} \mathrm{h}{ }^{-1}$ and ${ }^{137} \mathrm{Cs}$ below $150 \mathrm{kBq} \mathrm{m}^{-2}$, and the remediated areas of the forest showing dose rates below $0.70 \mu \mathrm{Gy} \mathrm{h}{ }^{-1}$ and ${ }^{137} \mathrm{Cs}$ below $300 \mathrm{kBq} \mathrm{m}^{-2}$. In contrast areas of the forest that have not been remediated show dose rates greater than $0.90 \mu \mathrm{Gy} \mathrm{h}^{-1}$ and ${ }^{137} \mathrm{Cs}$ greater than $300 \mathrm{kBq} \mathrm{m}{ }^{-2}$.

342 Comparison between the forest areas which had been remediated in 2012 and adjacent unremediated forest suggests a reduction in dose rate following remediation of approximately

344 35-60\%, consistent with earlier studies on other sites (Nakayama et.al. 2015, Sanderson et.al. 2016).

346 An average dose rate of $0.1 \mu \mathrm{Gy} \mathrm{h}^{-1}$ would result in an annual dose of approximately $1 \mathrm{mSv}$.

347 Current policy in Japan is to set a target level for protective measures in the lower part of the 348 1-20 $\mathrm{mSv} \mathrm{y}^{-1}$ range (NSC 2011). Thus the remediated sports fields are already at this target 
349 level, but the remediated forest areas are still at the higher end of the range for the policy 350 target.

351 The areas which had not been remediated in 2012 show similar values for the ${ }^{137}$ Cs activity 352 per unit area, despite variation in dominant tree type, which is consistent with previous 353 observations at the site which showed no difference in uncalibrated ${ }^{137} \mathrm{Cs}$ count rates at 354 ground level for deciduous and coniferous trees (Kato \& Onda 2014). However, in other 355 locations in Japan significantly elevated deposition has been observed for coniferous trees compared to deciduous (Yoshihara et.al. 2013, Sanderson et.al. 2016). This suggests local variation in the importance of foliar interception, with factors including the relative contributions of wet and dry deposition and stand density contributing.

In the areas where leaf litter was removed in 2012 there are differences observed in ${ }^{137} \mathrm{Cs}$ activity per unit area. In areas dominated by deciduous trees, predominantly to the east of the school, activity per unit area in the remediated forest ranges from approximately 100-200 $\mathrm{kBq} \mathrm{m}^{-2}$. Where coniferous trees dominate, activity per unit area is higher, between $150-250$ $\mathrm{kBq} \mathrm{m}^{-2}$. It is suggested that this reflects differences in interception and subsequent transport of radiocaesium. Conifers intercepted radiocaesium in the canopy, with transfer to needles which fall to the litter layer over several years. In March 2011 the deciduous trees would not have had leaves, and consequently interception of radiocaesium in the canopy would be much lower and a larger proportion would be deposited directly onto the ground surface. Therefore, when the litter layer was removed during 2012 a larger proportion of the activity was removed from the deciduous areas. Subsequent build up of litter would have included contaminated needles from the conifers with much lower concentrations of radiocaesium in the leaves of the deciduous trees. 
school entrance becomes increasingly evident over this period. A small enhancement in dose

375

376

377

378

379

380

381

382

383

384

385

386

387

388

389

390

391

392

393

394

395

396

397

398

rate to the south of the kindergarten on the $14^{\text {th }}-15^{\text {th }}$ November (Figs. $7(\mathrm{~b})$ and 8(b))

corresponds to an area used to stack branches removed from the trees that had been cut down.

The final survey concentrated on measurements of the areas that had previously been used as temporary stacks for branches and other tree material (predominantly in area D and F1), and the density of observations in the forest (area H1) is significantly lower than on the previous surveys. This has resulted in the stripes evident in Figs. 7(f) and 8(f), in particular for ${ }^{137} \mathrm{Cs}$, which are an artefact of the increased survey line spacing and are not considered to represent a difference in depositional pattern. For the area to the east of the buildings where trees were felled (areas E1 and E2), the ${ }^{137}$ Cs activity per unit area at the end of the experiment is very similar to the initial state. To the north of the buildings (area E3), the corresponding area where trees were felled has a slightly higher ${ }^{137}$ Cs activity per unit area.

The data collected on the $28^{\text {th }}$ April 2015 did not show as pronounced a soil water effect, and for these data the area to the east of the buildings (E1 and E2) shows a small decrease in ${ }^{137} \mathrm{Cs}$ activity per unit area with no significant change for the area to the north (E3). It appears that the effect of tree felling in reducing the ${ }^{137} \mathrm{Cs}$ inventory is different for these two areas, with it being more effective to the east of the buildings than the north.

Figure 9 shows the change in dose rate for the areas of main interest for this study, after regridding to allow for corrections due to environmental change and the physical decay of

${ }^{134} \mathrm{Cs}$. The uncertainties propagated through the analysis result in typically 5-10\% uncertainty on this change, corresponding to one or two colour divisions, with uncertainties being larger where the measurement density is lower and near the edges of the survey areas. The combination of measurement uncertainties and local redistribution of activity, over ranges of a few meters, results in a complicated visual pattern. However, some general observations can still be made from these maps of dose rate change. There are small reductions in dose rate 
observed with the felling of the trees (area E) particularly evident in Fig. 9(c), accompanied by temporary increases in dose rate in locations where cut branches were stacked prior to

401 removal (to the north and south of the kindergarten, parts of areas D and F1) in Figs. 9(a)decontamination, had a very small impact on dose rate with the exception of locations where this included removal of some of the stored branches, seen in comparisons of area D in Figs 9(a)-9(c) compared to 9(d). The area to which wood chips had been applied (to the south and east of the kindergarten, areas F1 and F2) shows a small further reduction in dose rate in Fig. 9(e).

\section{Conclusions}

410 The various measurements presented here all support the conclusion that, on this site,

411 felling trees coupled with the use of wood chips to cover the ground has produced reductions

412 of $15 \pm 5 \%$ in the dose rate for the area which was cleared, and slightly smaller dose rate

413 reductions in adjacent areas both within the forest $(12 \pm 4 \%)$ and in the open areas adjacent to

414 the forest (9 $\pm 4 \%)$. However, it also noted that $7 \pm 3 \%$ reductions are measured in some of the

415 areas of forest which were not subject to remediation, after consideration of the decay of

$416{ }^{134}$ Cs. Radiometric surveys on a cedar plantation near Iwaki have demonstrated reductions in

417 dose rate of 10-15\% over a year in some unremediated areas (Sanderson et.al. 2016), which is

418 not dissimilar to the reductions observed here. If similar reductions in dose rate would have

419 occurred in the remediated areas as a result of natural redistributive processes then this

420 reduces the overall effectiveness of the remediation conducted in these areas to

421 approximately 10-15\% reductions in dose rate. The reductions in dose rate that might be

422 achieved on other sites are likely to be variable, with dependencies on the particular

423 characteristics of each site, including tree species and topography. 
424 Although the felling of trees has a substantial impact on forest ecology, this does have an 425 appreciable immediate impact on dose rates near the forest edge which will contribute to

426

427

overall dose rate reductions in contaminated areas and ultimately to allowing evacuated residents to return to their homes. It is expected that the removal of trees, and hence a source of contaminated litterfall, will result in additional long term radiological benefits by reducing routes for recontamination of the remediated area. The Yamakiya study site will continue to be monitored over the next few years to evaluate this.

The dosimetry method using the convenient and sophisticated backpack system used in this work is widely applicable to decontamination work, and other studies, in Fukushima.

\section{Supplementary Material}

Table S.1: Data from scraper plate measurements at the Yamakiya school forest, July 2011 to 2015, and three cores collected in May 2016 from a second location within the forest.

Table S.2: Spot measurements $\left(\mu \mathrm{Gy} \mathrm{h} \mathrm{h}^{-1}\right.$ with the backpack, $\mu$ Sv $\mathrm{h}^{-1}$ with the TCS-172B dose rate meter) at the marked dose rate measurement points

Table S.3: Mean values for ${ }^{134} \mathrm{Cs}$ and ${ }^{137} \mathrm{Cs}$ activity per unit area, ${ }^{40} \mathrm{~K},{ }^{214} \mathrm{Bi}$ and ${ }^{208} \mathrm{Tl}$ activity per unit mass and dose rate measured with the backpack system for different areas of the Yamakiya site. Values in italics have been adjusted to correct for variable environmental conditions and with ${ }^{134}$ Cs decay corrected to $8^{\text {th }}$ November 2014.

Table S.4: Ratio of the mean ${ }^{40} \mathrm{~K}$ count rates for each survey relative to the initial survey on the 7-8th November 2014, for the hard surface areas and the forest areas. For the forest area the relative soil density is given, and correction factors for both radiocaesium and dose rate calculated from this relative soil density difference.

\section{Acknowledgments}


449 We thank Kawamata Town Office for permission to access the Yamakiya Elementary School 450 grounds and the surrounding forest for this study. Our thanks are also due to Mr Sato and Ms 451 Chiba for assistance clearing branches and spreading wood chips.

452 This research was financially supported by KAKENHI Grant Number 24110001 and 453 24110006, and part of the distribution-mapping project, which was financed by the Ministry 454 of Education, Culture, Sports, Science, and Technology, and the project on integrating 455 distribution data and development of transfer model regarding radioactive substances derived 456 from Fukushima Daiichi Nuclear Power Plant accident financed by the Nuclear Regulation 457 Authority, Japan. Funding was also provided through the forest project of the Institute of 458 Environmental Radioactivity, Fukushima University. 


\section{References}

462 Buchanan, E.; Cresswell, A.J.; Seitz, B.; Sanderson, D.C.W. Operator related attenuation 463 effects in radiometric surveys. Radiation Measurements 2016, 86, 24-31; doi 464 10.1016/j.radmeas.2015.15.029.

465

Cresswell, A.J.; Sanderson, D.C.W.; Harrold, M.; Kirley, B.; Mitchell, C.; Weir, A.

Demonstration of lightweight gamma spectrometry systems in urban environments. Journal

Cresswell, A.J.; Sanderson, D.C.W.; White, D.C. 137Cs measurement uncertainties and detection limits for airborne gamma spectrometry (AGS) data analysed using a spectral windows method. Applied Radiation and Isotopes 2006, 64, 247-253; DOI 10.1016/j.apradiso.2005.07.013

474

Hardie, S. M. L.; McKinley, I. G. Fukushima remediation: status and overview of future plans. Journal of Environmental Radioactivity 2014, 133, 75-85; DOI

478 temporal dynamics of radiocesium deposited onto forests following the Fukushima nuclear accident. Scientific Reports 2013, 3, srep02564. DOI: 10.1038/srep02564.

482

483 Airborne Gamma Ray Spectrometer Surveying; International Atomic Energy Agency:

484 Vienna, 1991; Technical Reports Series 323.

485 
Nakayama, S.; Kawase, K.; Hardie, S.; Yashio, S.; Iijima, K.; Mckinley, I.; Miyahara, K.;

Klein, L. Remediation of Contaminated Areas in the Aftermath of the Accident at the

Fukushima Daiichi Nuclear Power Station: Overview, Analysis and Lessons Learned. Part 1:

A Report on the “Decontamination Pilot Project” Japan Atomic Energy Agency, 2015;

Basic Policy of the Nuclear Safety Commission of Japan on Radiation Protection for

510 http://www.nsr.go.jp/archive/nsc/NSCenglish/geje/20110719suggest_4.pdf 
512 Sanderson, D.C.W.; Cresswell, A.J.; Tamura, K.; Iwasaka, T.; Matsuzaki, K. Evaluating

513 remediation of radionuclide contaminated forest near Iwaki, Japan, using radiometric

514 methods. Journal of Environmental Radioactivity 2016, 162-163, 118-128. doi:

$515 \quad$ 10.1016/j.jenvrad.2016.05.019

516

517 Sanderson, D.C.W.; Cresswell, A.J.; Seitz, B.; Yamaguchi, K.; Takase, T.; Kawatsu, K.;

518 Suzuki, C.; Sasaki, M. Validated Radiometric Mapping in 2012 of Areas in Japan Affected by

519 the Fukushima-Daiichi Nuclear Accident. University of Glasgow:Glasgow, UK, 2013; ISBN

520 978-0-85261-937-7; http://eprints.gla.ac.uk/86365/

521

522 Sanderson, D.C.W.; Cresswell, A.J.; White D.C. The effect of flight line spacing on

523 radioactivity inventory and spatial feature characteristics of airborne gamma-ray

524 spectrometry data. International Journal of Remote Sensing 2008, 29, 31-46; DOI

$525 \quad 10.1080 / 01431160701268970$

526

527 Sanderson, D.C.W.; Cresswell, A.J.; Scott, E.M.; Lang, J.J. Demonstrating the European capability for airborne gamma spectrometry: results from the ECCOMAGS exercise.

Radiation Protection Dosimetry 2004, 109, 119-125; DOI 10.1093/rpd/nch243

530

531 Sanderson, D. C. W.; Allyson, J. D.; Tyler A. N. Rapid quantification and mapping of

532 radiometric data for anthropogenic and technically enhanced natural nuclides. In Application

533 of Uranium Exploration Data and Techniques in Environmental Studies; IAEA: Vienna 534 1994; IAEA TECDOC-827. pp 197-216.

535 
536 Takahashi, J.; Tamura, K.; Suda, T.; Matsumura, R.; Onda, Y. Vertical distribution and

537 temporal changes of 137Cs in soil profiles under various land uses after the Fukushima Dai-

538 ichi Nuclear Power Plant accident. Journal of Environmental Radioactivity 2015, 139, 351-

539 361; DOI 10.1016/j.jenvrad.2014.07.004

540

541 Tyler, A.N., Sanderson, D.C.W., Scott, E.M., Allyson, J.D. Accounting for Spatial

542 Variability and Fields of View in Environmental Gamma Ray Spectrometry. Journal of

543 Environmental Radioactivity 1996, 33, 213-235.

544

545 Yoshihara, T.; Matsumura, H.; Hashida, S.; Nagaoka, T. Radiocesium contaminations of 20

546 wood species and the corresponding gamma-ray dose rates around the canopies at 5 months

547 after the Fukushima nuclear power plant accident. Journal of Environmental Radioactivity

548 2013, 115, 60-68. doi: 10.1016/j.jenvrad.2012.07.002

549

550 


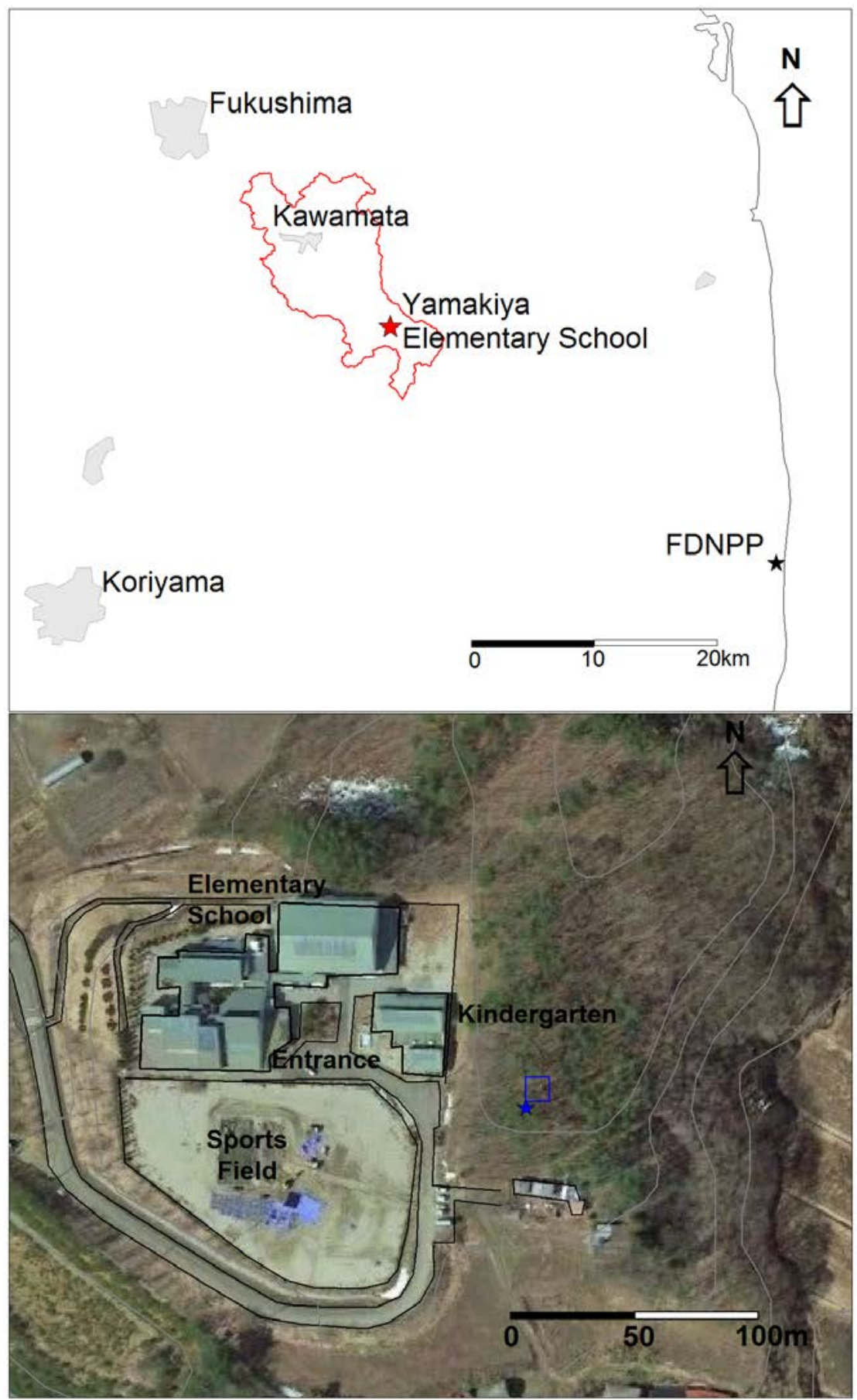

551

552 Figure 1. Location of the former Yamakiya Elementary School and forest (top), and the

553 buildings within the school (bottom). The location of the Takahashi et.al. (2015) sampling

554 site is indicated by the blue star, just to the south of the monitoring tower (Kato and Onda

555 2014, Kato et.al. 2015) indicated by the blue square. Aerial photograph (c) 2015 Google.

556 Image (C) 2015 ZENRIN. 

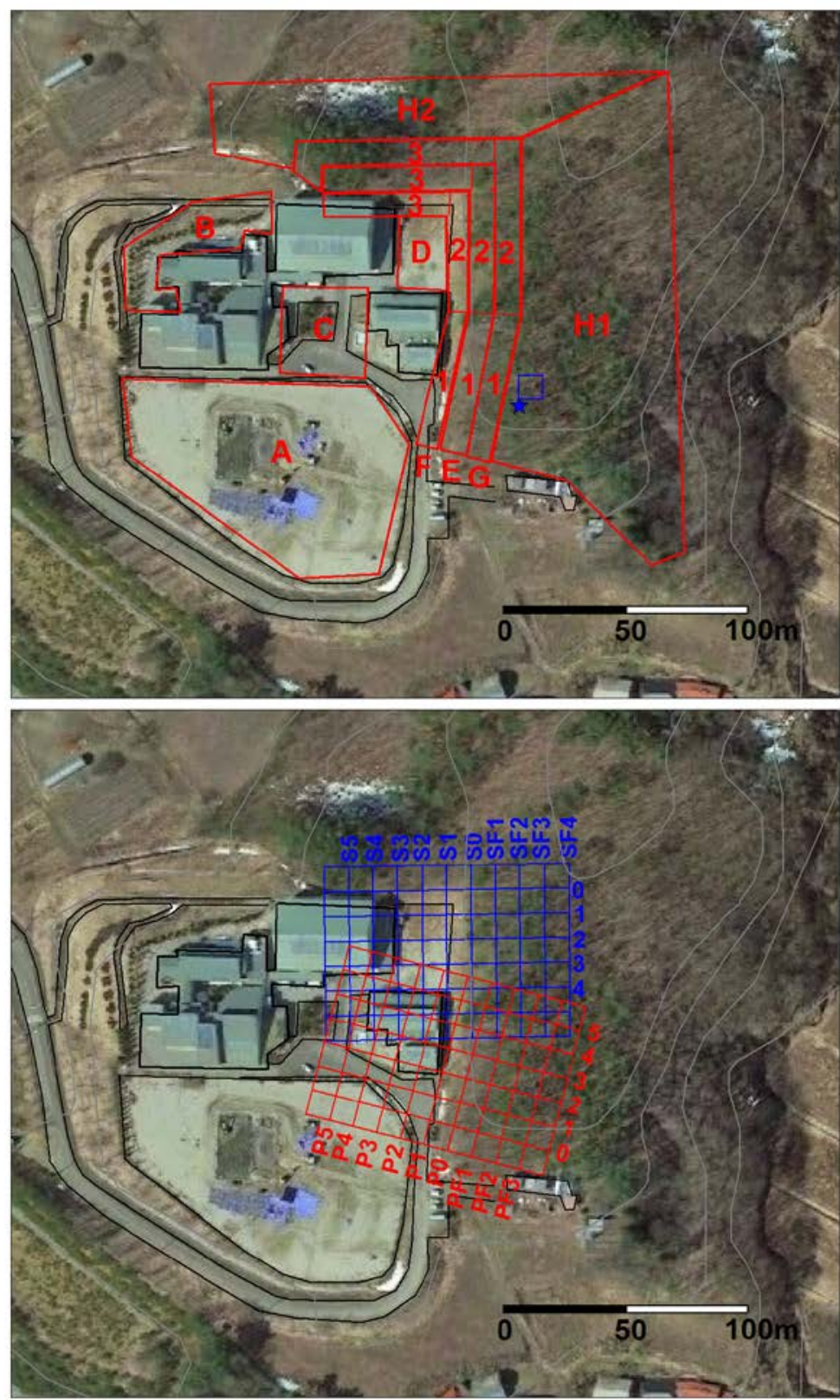

557 Figure 2. Location of survey area divisions (top), and dose rate measurement grids (bottom).

558 Aerial photograph (C) 2015 Google. Image (C) 2015 ZENRIN. 

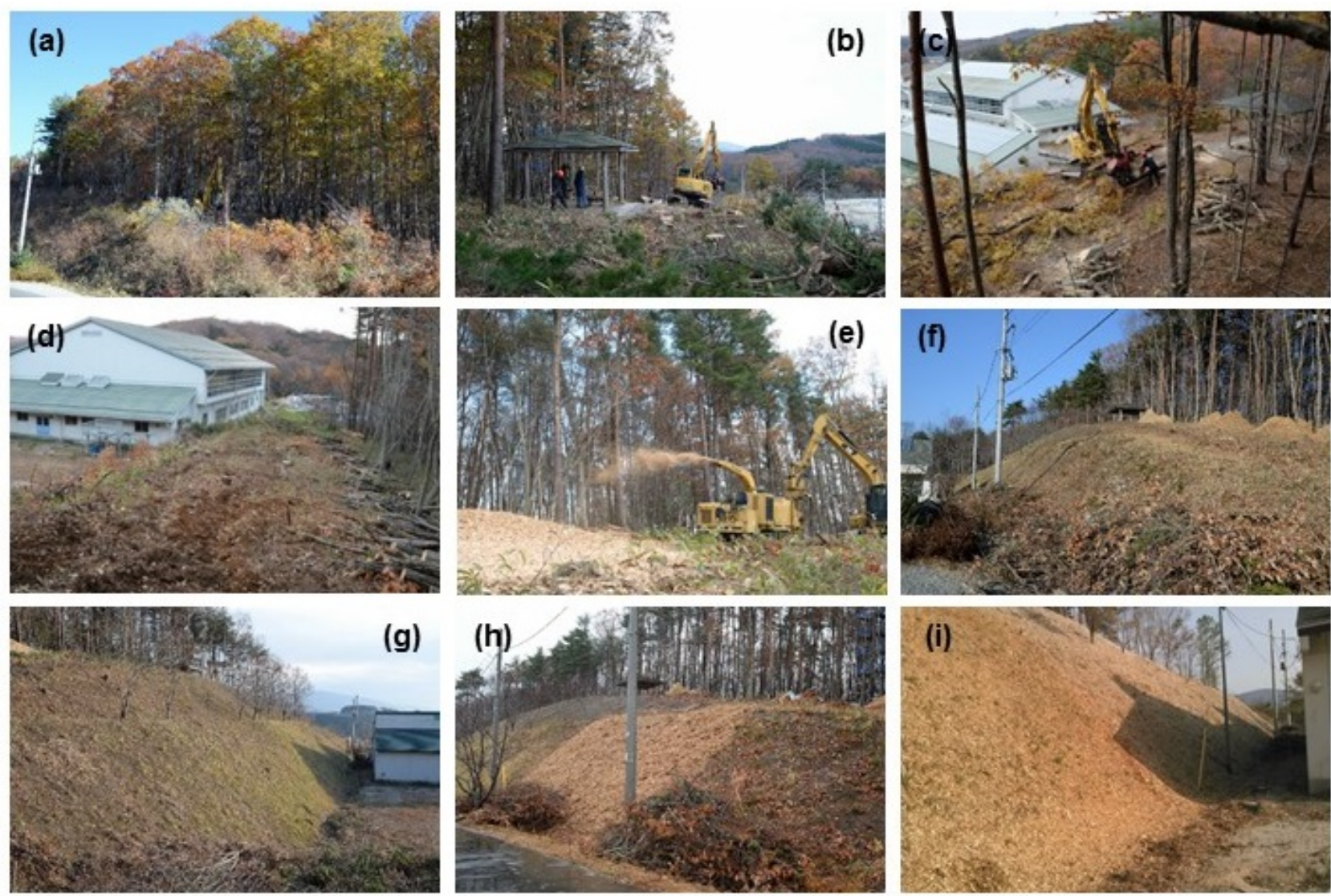

560 Figure 3. Photographs illustrating the different stages of remediation. (a) area E1 before

561 felling of trees, (b)-(c) areas E1 and E2 during tree felling, (d) area E1 after felling of trees,

562 (e) production of wood chips in area E2, (f) area F1 and (g) area F2 after production of wood

563 chips, (h) after application of wood chips on part of area F1, and (i) after application of wood

564 chips to whole of areas F1 and F2.

565 


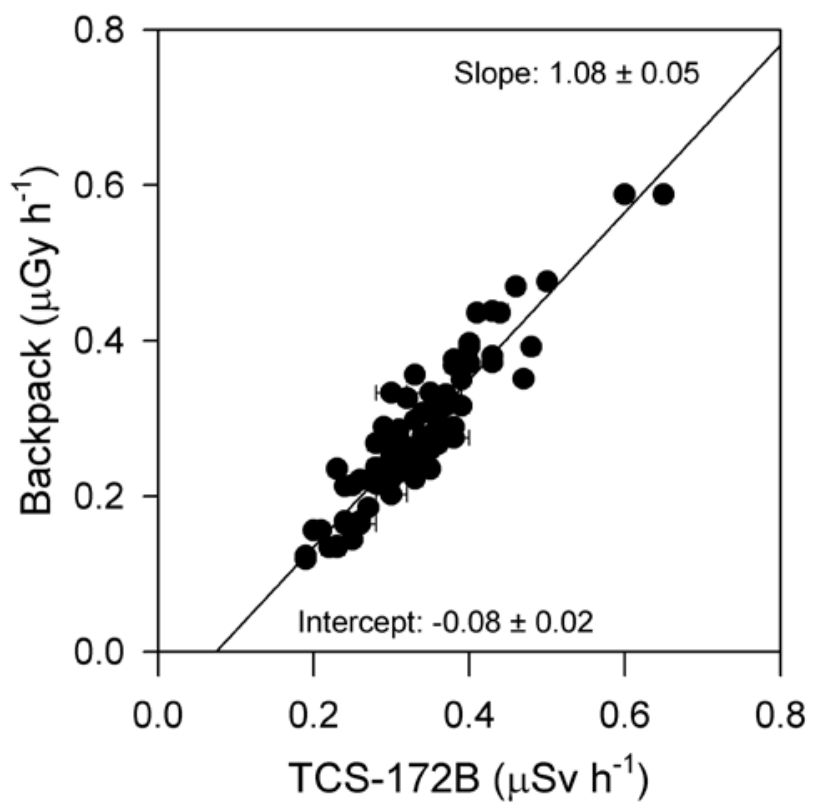

566 Figure 4. Comparison between dose rates measured with a survey meter and the backpack 567 system.

568 

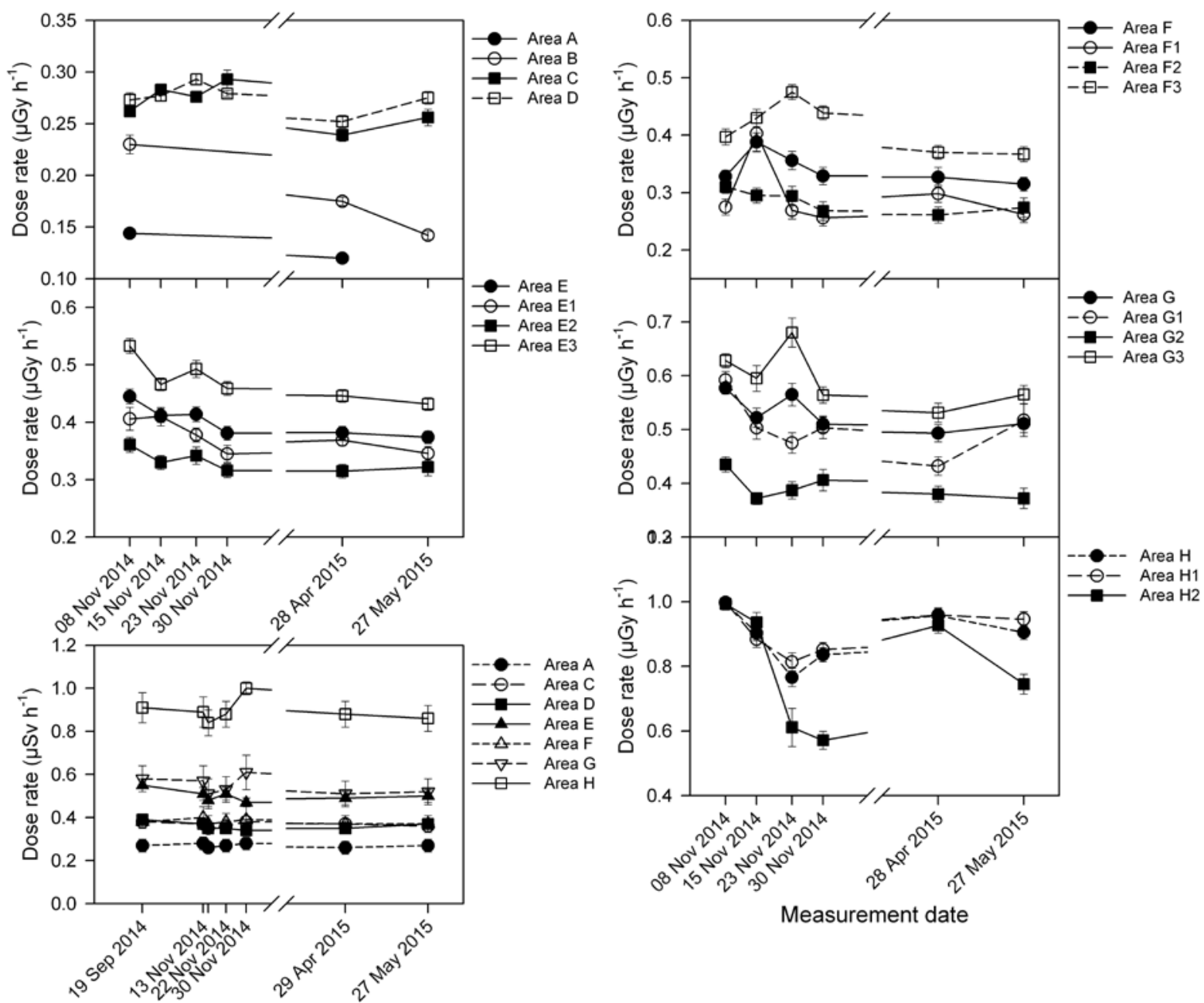

570

Measurement date

571 Figure 5. Variation in dose rate measured with the backpack system, after adjustments for

572 environmental variations and ${ }^{134}$ Cs decay, with time for the artificial surfaces (A-D, top left),

573 the forest area that had been felled (E, middle left), the slope between the felled forest and the

574 school (F, top right), the unfelled forest previously remediated ( $\mathrm{G}$, middle right) and the rest

575 of the forest (H, bottom). Dose rate measurements with the TCS-172B survey meter are

576 shown (bottom left) 
578

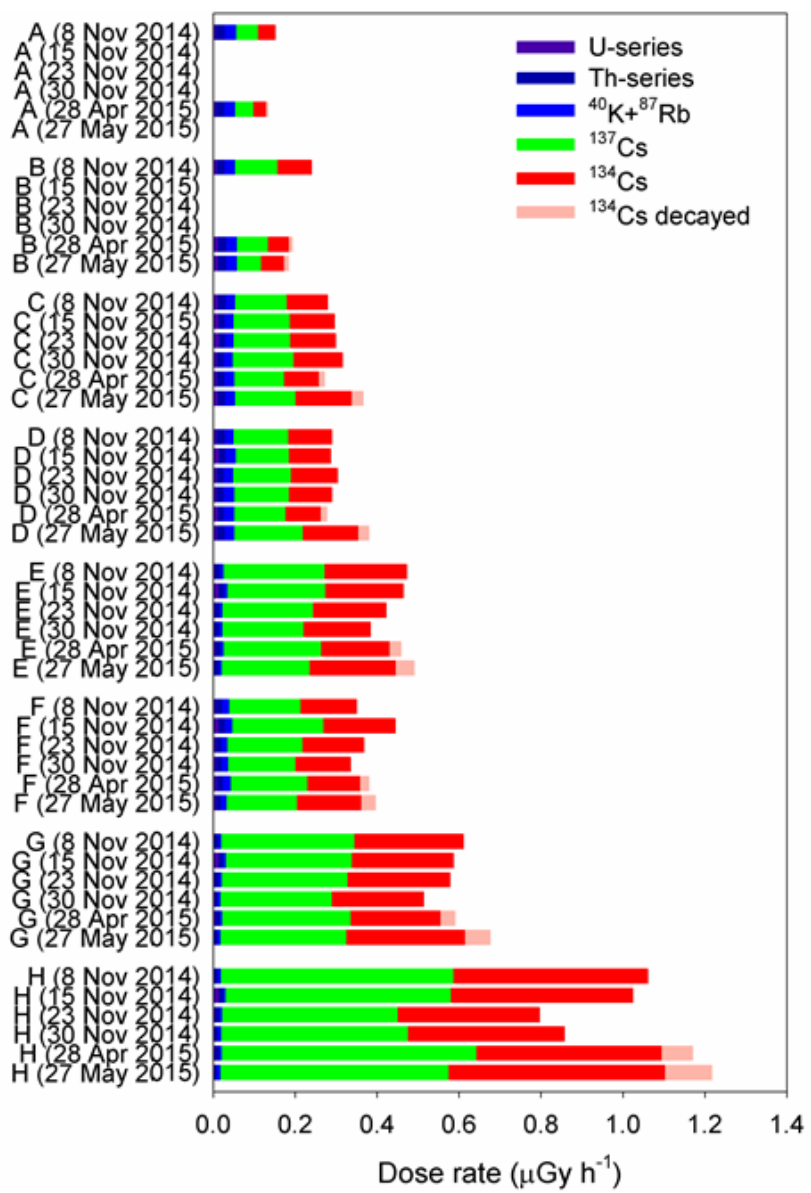

579 Figure 6. Dose rate apportionments at different parts of the site, as shown in Fig. 2 and listed

580 in Table 1, at each stage of the experiment. The areas that have been sub-divided in Fig. 2

581 have been combined here.

582 

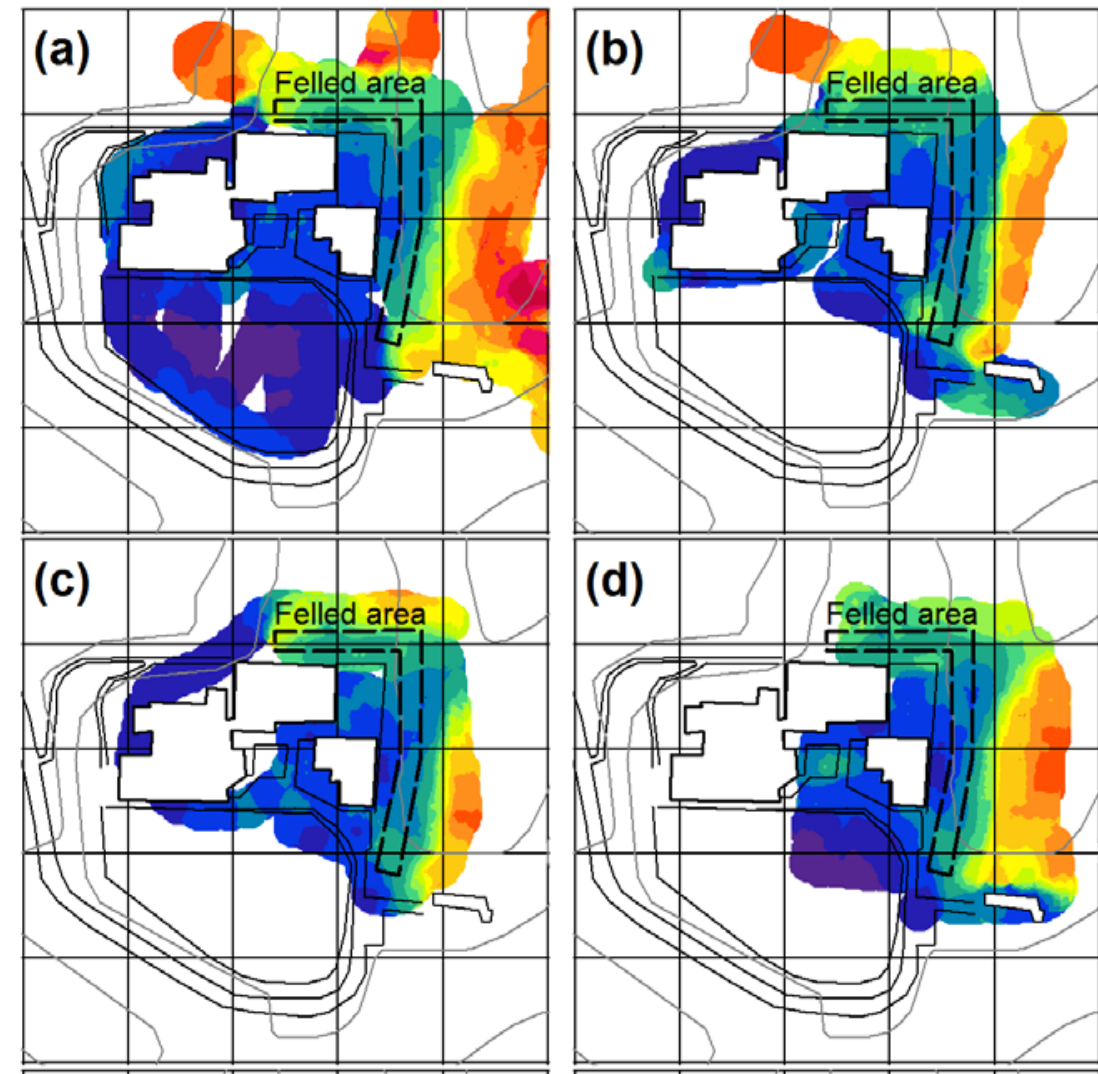

\section{Gamma Dose Rate $\left(\mu \mathrm{Gy} \mathrm{h}{ }^{-1}\right)$}
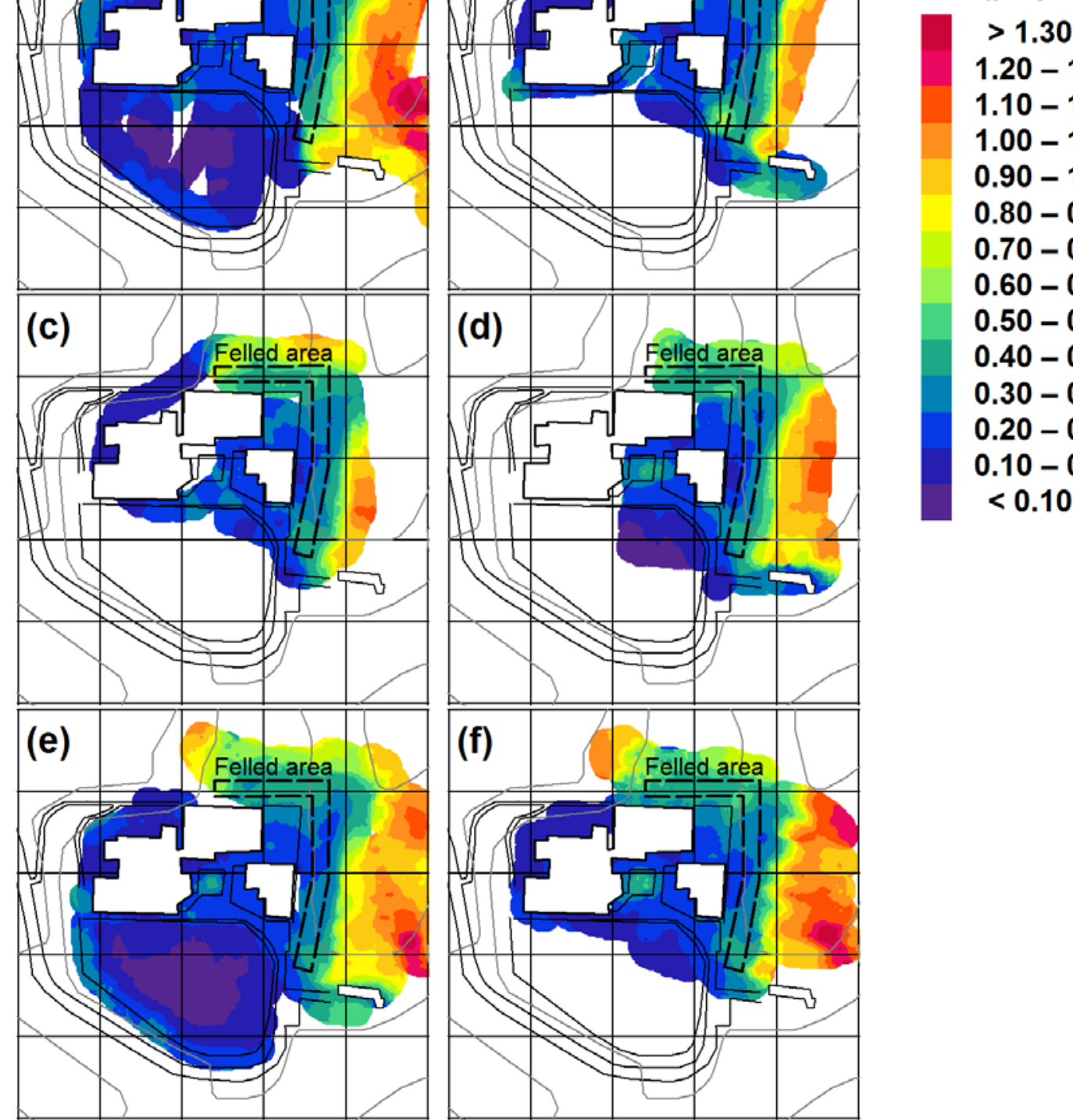

$1.20-1.30$

$1.10-1.20$

$1.00-1.10$

$0.90-1.00$

$0.80-0.90$

$0.70-0.80$

$0.60-0.70$

$0.50-0.60$

$0.40-0.50$

$0.30-0.40$

$0.20-0.30$

$0.10-0.20$

$<0.10$

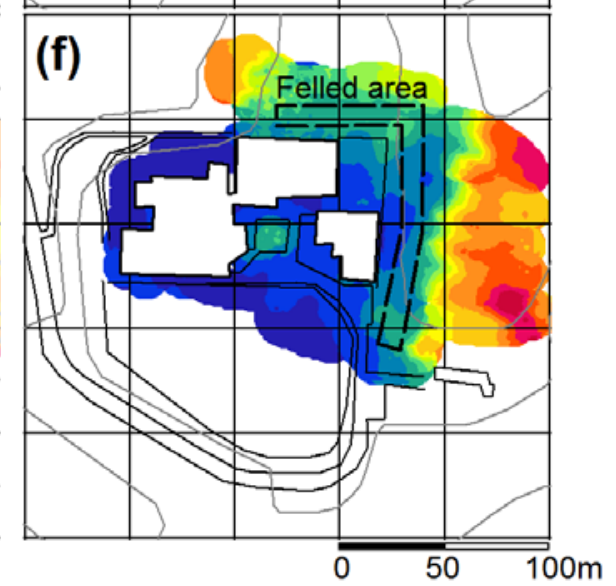

583 Figure 7. Gamma dose rate distribution during the experiment. (a) $7^{\text {th }}-8^{\text {th }}$ November 2014 ,

584 (b) $14^{\text {th }}-15^{\text {th }}$ November 2014, (c) $23^{\text {rd }}$ November 2014, (d) $30^{\text {th }}$ November 2014, (e) $28^{\text {th }}$ April 5852015 and (f) $27^{\text {th }}$ May 2015.

586 

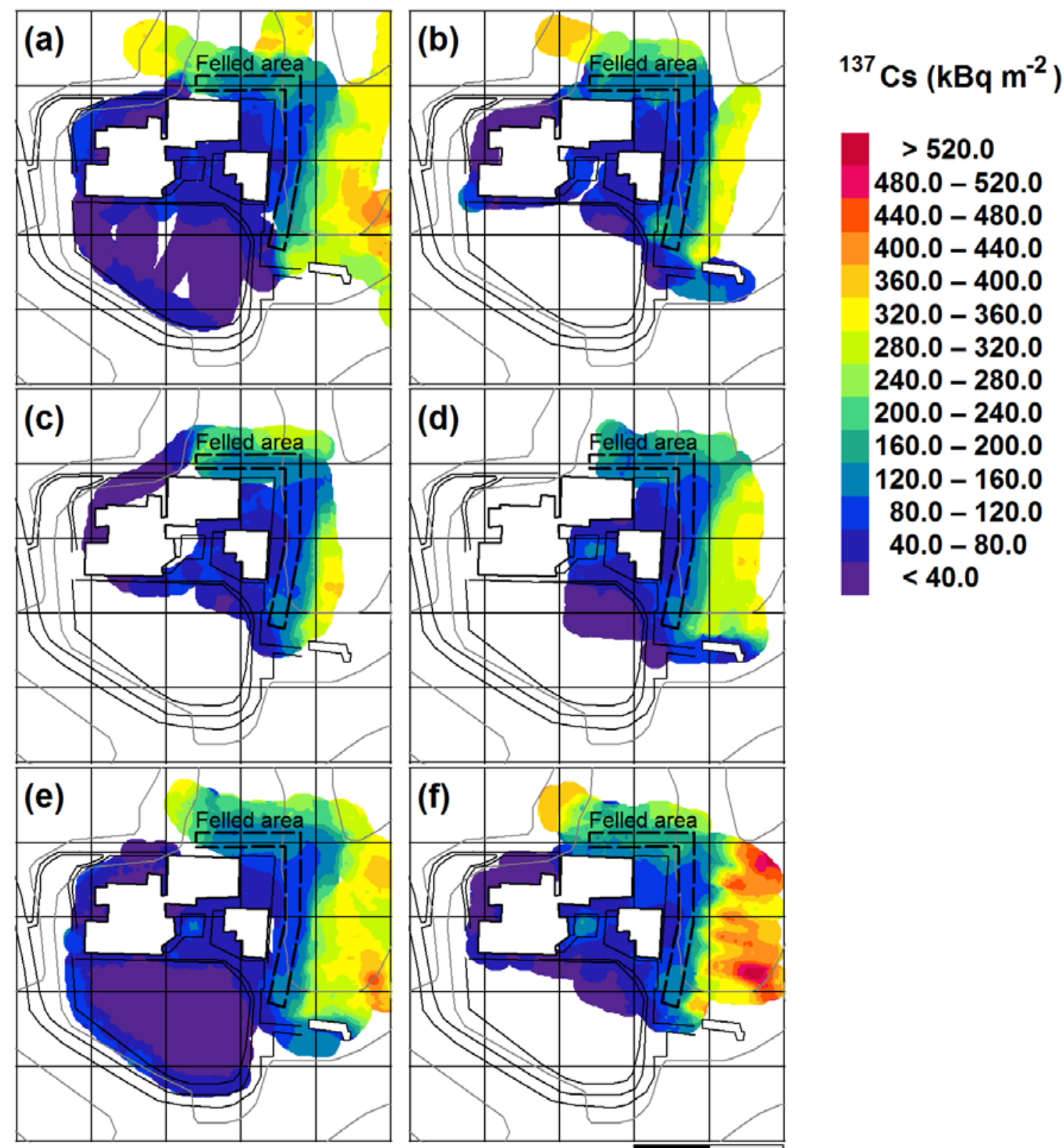

587 Figure 8. ${ }^{137}$ Cs activity per unit area distribution during the experiment. (a) $7^{\text {th }}-8^{\text {th }}$ November

5882014 , (b) $14^{\text {th }}-15^{\text {th }}$ November 2014, (c) $23^{\text {rd }}$ November 2014, (d) $30^{\text {th }}$ November 2014, (e)

$58928^{\text {th }}$ April 2015 and (f) $27^{\text {th }}$ May 2015.

590 

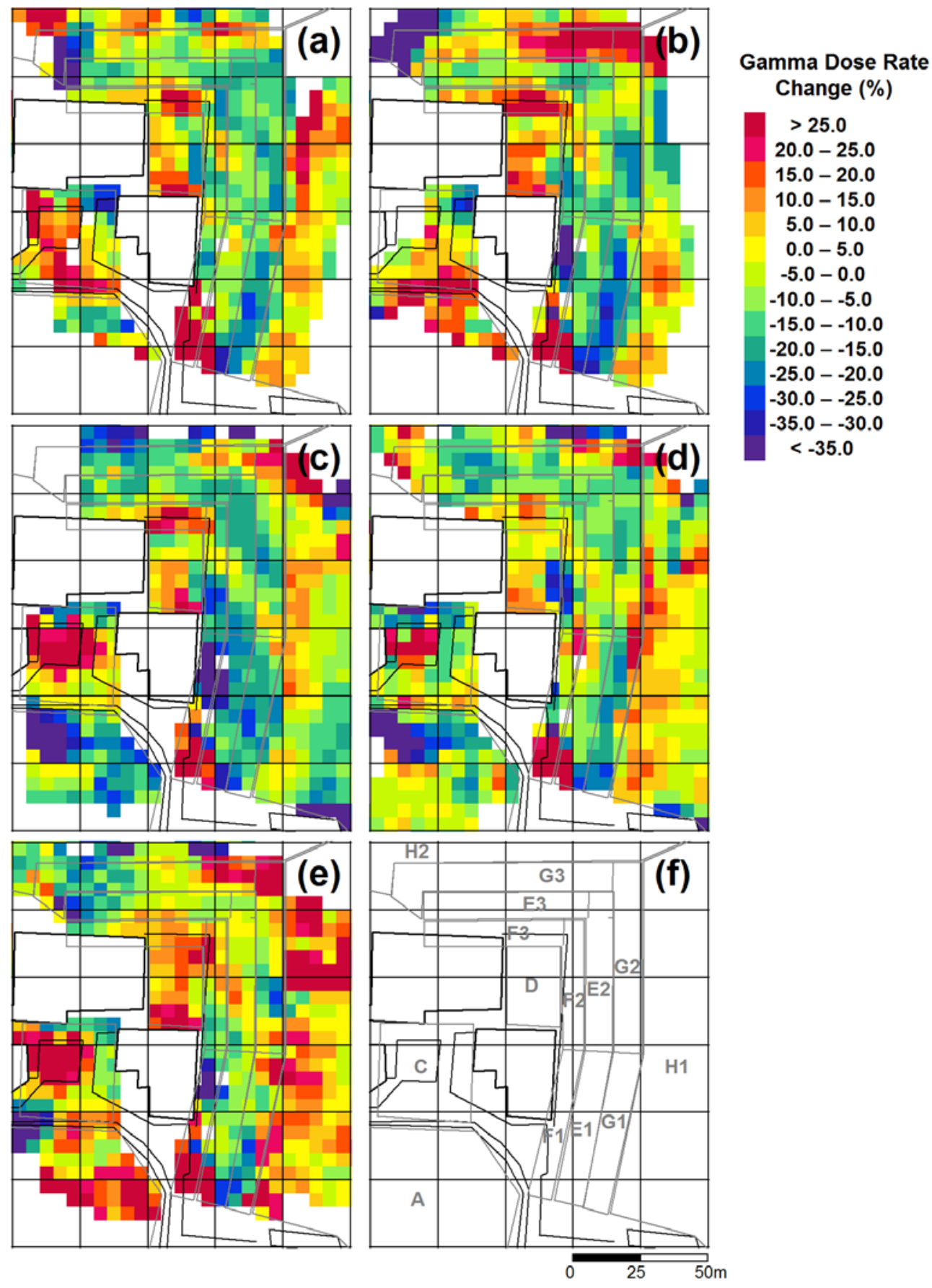

593 Figure 9. Dose rate changes relative to the initial survey $\left(7-8^{\text {th }}\right.$ November 2014$)$, with

594 oranges and reds indicating an increase in dose rate and greens and blues a decrease,

595 following corrections for environmental conditions and physical decay. Uncertainties are

596 typically 5-10\% (one or two colour bands) (a) Following removal of trees $\left(14-15^{\text {th }}\right.$ November

597 2014), (b) following removal of litter (23 ${ }^{\text {rd }}$ November 2014), (c) following application of

598 wood chips to part of the site (30 $0^{\text {th }}$ November 2014), (d) following completion of application 
599 of wood chips ( $28^{\text {th }}$ April 2015) and (e) following removal of the last of the cut trees $\left(27^{\text {th }}\right.$ 600 May 2015). The subdivided areas (Fig.2 and Table 1) are indicated by the grey lines, and 601 labelled (f).

602 


\begin{tabular}{|c|c|}
\hline Area & Description \\
\hline A & Sports field south of the school buildings \\
\hline B & $\begin{array}{l}\text { Footpath and line of trees to the north and west of the two parts of the Elementary } \\
\text { School building }\end{array}$ \\
\hline $\mathrm{C}$ & $\begin{array}{l}\text { Area outside the Elementary School entrance, between the school and kindergarten, } \\
\text { including an ornamental shrubbery }\end{array}$ \\
\hline $\mathrm{D}$ & $\begin{array}{l}\text { Open area to the north of the kindergarten and east of the Elementary school } \\
\text { buildings }\end{array}$ \\
\hline $\mathrm{E}$ & $\begin{array}{l}10 \text { m wide forested area along the top of the slope east of the school buildings and to } \\
\text { the north of area D. This is subdivided into three sub-areas; E1 and E2 to the east of } \\
\text { the school buildings, E3 to the north. This area had previously been remediated by } \\
\text { removal of leaf litter. } \\
\text { Trees in this area were felled for this experiment. }\end{array}$ \\
\hline $\mathrm{F}$ & $\begin{array}{l}\text { Slope between the forest and the school buildings, which levels off at the western } \\
\text { end of the northern section. This is subdivided into three sub-areas; F1 and F2 to the } \\
\text { east of the school buildings, F3 to the north. } \\
\text { Wood chips were applied to sub-areas E1 and E2 for this experiment. }\end{array}$ \\
\hline G & $\begin{array}{l}10 \text { m wide strip of forest to the east and north of area E. This is subdivided into three } \\
\text { sub-areas; G1 and G2 to the east of the school buildings, G3 to the north. } \\
\text { This area had previously been remediated with the removal of leaf litter. }\end{array}$ \\
\hline $\mathrm{H}$ & $\begin{array}{l}\text { The remaining forestry around the school. This is subdivided into two sub-areas; H1 } \\
\text { to the east and H2 to the north. Sub-area H1 is mixed woodland, sub-area H2 } \\
\text { includes stands of red pine. }\end{array}$ \\
\hline
\end{tabular}

Table 1: Description of survey area divisions shown in Fig. 2. 


\begin{tabular}{|c|c|c|c|}
\hline Date & Stage & Area surveyed & $\begin{array}{l}\text { Approximate number of } \\
\text { measurements }\end{array}$ \\
\hline $\begin{array}{l}7^{\text {th }}-8^{\text {th }} \text { Nov } \\
2014\end{array}$ & Prior to tree felling & $\begin{array}{l}\text { School grounds, all forest to } \\
\text { the east, parts of forest to the } \\
\text { north including all areas } \\
\text { previously remediated }\end{array}$ & 1500 \\
\hline $\begin{array}{l}14^{\text {th }}-15^{\text {th }} \text { Nov } \\
2014\end{array}$ & After tree felling & $\begin{array}{l}\text { School grounds excluding } \\
\text { playground, forest 10-20 m } \\
\text { beyond felled area }\end{array}$ & 1200 \\
\hline $\begin{array}{l}23^{\text {rd }} \text { Nov } \\
2014\end{array}$ & $\begin{array}{l}\text { Following removal of } \\
\text { litter }\end{array}$ & $\begin{array}{l}\text { School grounds excluding } \\
\text { playground, forest 10-20 m } \\
\text { beyond felled area }\end{array}$ & 700 \\
\hline $\begin{array}{l}30^{\text {th }} \text { Nov } \\
2014\end{array}$ & $\begin{array}{l}\text { Following application of } \\
\text { wood chips to part of the } \\
\text { area }\end{array}$ & $\begin{array}{l}\text { School grounds within } 50 \mathrm{~m} \text { of } \\
\text { forest, forest } 10-20 \mathrm{~m} \text { beyond } \\
\text { felled area }\end{array}$ & 700 \\
\hline $\begin{array}{l}28^{\text {th }} \text { Apr } \\
2015\end{array}$ & $\begin{array}{l}\text { Following removal of cut } \\
\text { wood around school and } \\
\text { application of wood chips } \\
\text { to entire area }\end{array}$ & $\begin{array}{l}\text { School grounds, all forest to } \\
\text { the east, parts of forest to the } \\
\text { north including all areas } \\
\text { previously remediated }\end{array}$ & 1800 \\
\hline $\begin{array}{l}27^{\text {th }} \text { May } \\
2015\end{array}$ & $\begin{array}{l}\text { Following removal off all } \\
\text { branches and other } \\
\text { material }\end{array}$ & $\begin{array}{l}\text { School grounds within } 50 \mathrm{~m} \text { of } \\
\text { forest, all forest areas }\end{array}$ & 1000 \\
\hline
\end{tabular}

Table 2. Summary of surveys conducted. 